\title{
Cost-effectiveness analysis of hernioplasties before and after the implementation of the ACERTO project
}

\section{Análise da custo-efetividade em hernioplastias antes e após a implementação do projeto ACERTO}

José Eduardo de Agullar Nascimento, TCBC-MT1,2 (iD; Alberto Bicudo Salomäo, tCbC-MT³; Mara Regina Rosa Ribeiro 3,4 ; Roberta Ferreira da Silva ${ }^{3}$; Wesley Santana Correa Arruda².

\begin{abstract}
A B S T R A C T
Objective: to compare hospital costs and clinical outcomes in inguinal and incisional hernioplasty before and after implementation of the ACERTO project in a university hospital. Methods: retrospective study of 492 patients undergoing either inguinal hernioplasty ( $n=315)$ or incisional hernioplasty $(n=177)$. The investigation involved two phases: between January 2002 and December 2005, encompassing cases admitted before the implementation of the ACERTO protocol (PRE-ACERTO period), and the other phase, with cases operated between January 2006 and December 2011, after the implementation of the protocol (ACERTO period). The main outcome variable was the comparison of the mean hospital costs between the two periods. As secondary endpoints, we analyzed the length of stay, the surgical site infection rate and mortality. We used the cost method suggested by Public Sector Cost Information System. Results: surgical site infection was higher $(p=0.039)$ in the first phase of the study for both inguinal hernia operations $(2(1.6 \%)$ versus $0(0 \%)$ cases $)$ and incisional hernioplasty $(5(7.6 \%)$ versus $3(2.7 \%)$ cases). The length of stay decreased one day after the implementation of the ACERTO protocol $(p=0.005)$. There was a reduction in costs per patient from $R \$ 4,328.58$ per patient in the first phase to $R \$ 2,885.72$ in the second phase ( $66.7 \%$ reduction). Conclusion: there was a reduction in infectious morbidity, length of stay and hospital costs in hernioplasty after the implementation of the ACERTO protocol.
\end{abstract}

Keywords: Hospital Costs. Herniorrhaphy. Surgical Wound Infection. Preoperative Care. Postoperative Care.

\section{INTRODUCTION}

$\mid$ of n 2005, the Department of Surgical Clinics of the Faculty I of Medical Sciences of the Federal University of Mato Grosso (FCM - UFMT) started using the set of routines in order to accelerate the recovery of patients undergoing abdominal operations ${ }^{1}$. Based on the European protocol ERAS ${ }^{2}$, the project involved in the implementation of these routines, appropriate to the reality of that hospital, received the name ACERTO. That name is an acronym for the full name of the project: "aceleração da recuperação total" (in Portuguese, acceleration of total recovery) of the patient in the postoperative period. The word "acerto" has a Latin origin and means "getting it right", in the sense of discovering the true, harmonizing, reaching the target ${ }^{3}$.
The ACERTO protocol aims to reduce costs and unfavorable outcomes both in private hospitals and those in the public network, and to improve results even in medium-sized operations. Several studies have reported benefits in cholecystectomy ${ }^{4,6}$, but no investigation has been done in operations to treat abdominal wall hernias. Hernioplasties correspond to the second most performed operation in the Brazilian health system and the General Surgery field in Brazil, between the years 1995 to $2007^{7}$.

After the implementation of the ACERTO protocol at the Julio Muller University Hospital, it is necessary to investigate costs and clinical outcomes, comparing them before and after the introduction of the new routines. Studies published and focused on results after ACERTO investigated only outcomes such as length of stay, morbidity and mortality, reporting improvement

1 - UNIVAG, Diretoria - Várzea Grande - MT - Brasil 2 - Universidade Federal de Mato Grosso, Pós-graduação em Ciências da Saúde - Cuiabá - MT Brasil 3 - Universidade Federal de Mato Grosso, Programa de Pós-Graduação em Ciências Aplicadas à Atenção Hospitalar do Hospital Universitário Julio Muller. - Cuiabá - MT - Brasil 4 - Universidade Federal de Mato Grosso, Faculdade de Enfermagem - Cuiabá - MT- Brasil 
after the implementation of the protocol ${ }^{1,8,9}$. This investigation aimed to compare hospital costs and clinical outcomes in inguinal and incisional hernioplasties before and after the implementation of the ACERTO project in that service.

\section{METHODS}

This study was submitted to evaluation and approved by the Ethics in Research Committee (CEP) of the HUJM (CAAE: 22803019.4.0000.5541; in 2019). Prospective data had been collected on the surgical procedures of 492 elective patients at the General Surgery Service (Department of Clinical Surgery) of the HUJM of FCM-UFMT, between January 2002 and December 2011.
The Department of Surgery Clinics has a prospective audit system since 2002, the details of which have been previously described ${ }^{1,3}$. Of these patients, 315 underwent inguinal hernioplasties and 177 incisional hernioplasties. The investigation involved two phases: between January 2002 and December 2005, covering cases admitted before the implementation of the ACERTO protocol (pre-ACERTO period), and the other, with cases operated between January 2006 and December 2011, after its implantation (ACERTO period). Table 1 shows the set of measures established by ACERTO and the conventional procedures that had been applied before its implementation for hernioplasties. According to the service routine, All patients were submitted to nutritional assessment by the global subjective assessment, as previously described ${ }^{1}$.

Table 1. Conducts applied in the general surgery ward of the HUJM before and after the implementation of the ACERTO project for hernioplasties.

Conventional conducts
Conducts recommended by the ACERTO protocol

- No prolonged preoperative fasting. Use of a liquid diet enriched with carbohydrate (12\% maltodextrin) until the day before the operation, with the possibility of ingestion up to 2 hours before the operation (3h in case of morbid obesity). Exception: important gastroesophageal reflux and pyloric stenosis syndrome.

- Diet reestablished in the afternoon for operations carried out in the morning or on the next day for thee ones performed in the afternoon.

- Postoperative venous hydration at a volume of $40 \mathrm{~mL}$ $\mathrm{kg}$.

- Diet after the operation as soon as cleared by the anesthesiologist (if possible, in the anesthetic recovery room).

- Intravenous hydration should not be prescribed in hernioplasties, in the immediate postoperative period, unless justified.

- Consent form and detailed preoperative information to the patient. Encourage the patient to walk and feed early in the postoperative period.

- Use of drains, catheters and antibiotics as preferred by the surgeon.

- Early postoperative mobilization.

- No use of prophylactic drains.

- Justified and standardized use of antibiotics.

- Ultra-early mobilization: sitting and walking on the same day of the operation for at least two hours, and for six hours on the following days.

- Oral supplement when at nutritional risk. 
The main outcome variable was the average cost of hospitalization, comparing the two periods studied according to the method described below. As a secondary outcome, we analyzed length of stay, surgical site infection (SSI), and mortality in both periods. SSI was defined according to the criteria proposed by Mangram et al. ${ }^{10}$. Only SSIs that were diagnosed during the hospital stay were evaluated.

\section{COST ANALYSIS}

We used the costs accrual method according to NBCT 16.11 - Public Sector Cost Information System ${ }^{11}$. To obtain the average cost of hospitalization per patient per day, we divided the total costs of hospitalization in the Surgical Clinics Department by the patient/day annual average. As for the calculation of the average cost per number of hospitalizations, we divided the total costs of admissions to the Surgical Clinics by the number of hospitalizations performed in each period. Finally, the value of the average cost of hospitalization per night consisted of dividing the total costs of admission to the Surgical Clinic by the number of daily rates in the period. These calculations can be seen in Table 2. For the purposes of calculating the average cost of hospitalization at the surgical clinics of the HUJM, we used the following data: 1) product output report by sector issued by the MV 2000 inventory control system; 2) laboratory and image examination report issued by the MV 2000 exam billing system; 3) authorizations for hospital admission (AlH) movement report - reduced files and rejected $\mathrm{AlH}$ issued by the DataSUS/Tabwin system; 4) personnel data sheet for public employees provided by the HUJM human resources unit; 5) personnel data from the servants of the single legal regime (RJU) provided by the HUJM expense settlement and payment unit; 6) work schedule available on the HUJM website; 7) information on the number of equipment in the operating room provided by the head of that unit; 8) data of the clinical engineering contract, as well as footage of the HUJM hospital areas made available by the logistics and infrastructure division; and 9) information on accommodation costs obtained by the hospital accommodation indicators monitoring panel and made available by the hospital accommodation unit. We thus obtained the value of $R \$ 1,442.86$ for the daily cost (Table 2).
Table 2. Values used to calculate the cost of hospitalization at the Hospital Universitário Julio Muller.

$$
\text { Variable }
$$

$R \$$

Average costs for hospitalization Patient/day $(\mathrm{R} \$)$

Average hospitalization costs Number of admissions

Average costs for hospitalization Surgical clinics daily rates

\section{STATISTICAL ANALYSIS}

We assessed normality of the continuous variables with the Kolmogorov-Smirnov test, and the homogeneity of their variances, with the Levene test. To compare the length of hospital stay, we used the MannWhitney test. We expressed the data on length of stay as median and interquartile range or as mean and standard error. We analyzed categorical variables (surgical site infection and deaths) using the chi-square or Fischer tests. We adopted a value of $p<0.05$ as the statistical significance threshold. As a measure of the association strength, we calculated the relative risk (RR), with a 95\% confidence interval $(95 \% \mathrm{Cl})$.

\section{RESULTS}

During the study period, 492 patients underwent inguinal $(n=315 ; 64 \%)$ or incisional $(n=$ $177 ; 36 \%$ ) hernioplasty. Table 3 shows the characteristics of the operated patients. There was a greater number of incisional hernias operated on in the period after the implementation of the ACERTO protocol. According to the ACERTO protocol, 22 patients received protein supplementation for a minimum of five days before surgery. In contrast, no patient received supplementation in the first phase of the study.

Table 4 shows the clinical results observed in the two study periods. There were about three times more SSIs in the phase before the ACERTO protocol, with a significant difference $(p=0.039)$. The occurrence of SSI was higher in the first phase of the study, both for operations of inguinal (2 (1.6\%) versus $0(0 \%)$ cases) and incisional hernioplasties (5 (7.6\%) versus $3(2.7 \%)$ cases). 
Hospitalization time decreased by one day after the implementation of the ACERTO protocol (table 3), both for the treatment of inguinal hernias $(3.08(0.21) \times 2.73$ (0.13) days; $p=0.005)$ and for incisional ones (6.57 (1.15) $\times 5.04(0,58)$ days; $p=0.006)$. The length of hospital stay was significantly shorter after the implementation of the ACERTO protocol. There were deaths $(n=2)$ only in the first phase, however, there was no difference in mortality. Both deaths were due to multiple organ failure following clinical complications.

Table 3. Characteristics of patients operated on in the pre-ACERTO periods and after the implementation of the ACERTO protocol.

\begin{tabular}{|c|c|c|c|c|c|}
\hline & \multicolumn{2}{|c|}{ Pre-ACERTO } & \multicolumn{2}{|c|}{ ACERTO } & $p$ \\
\hline Operations & \multicolumn{2}{|c|}{$190(38.6)$} & \multicolumn{2}{|c|}{$302(61.4)$} & \\
\hline \multicolumn{6}{|l|}{ Type of hernia (n; \%) } \\
\hline Inguinal & \multirow{2}{*}{\multicolumn{2}{|c|}{$\begin{array}{c}124(65.3) \\
66(34.7)\end{array}$}} & \multirow{2}{*}{\multicolumn{2}{|c|}{$\begin{array}{l}191(63.3) \\
111(36.7)\end{array}$}} & \\
\hline Incisional & & & & & 0,65 \\
\hline \multirow[t]{2}{*}{ Gender (n, \%) } & Masc. & Fem. & Masc. & Fem. & \\
\hline & 139 & 51 & 235 & 67 & 0.24 \\
\hline Median age (interquartile range) & \multicolumn{2}{|c|}{$50(23)$} & \multicolumn{2}{|c|}{$48.5(24)$} & 0.31 \\
\hline Malnutrition (n,\%) & \multicolumn{2}{|c|}{$55(28.9)$} & \multicolumn{2}{|c|}{$77(25.5)$} & 0,40 \\
\hline Preoperative oral supplement $(n, \%)$ & \multicolumn{2}{|c|}{0} & \multicolumn{2}{|c|}{$22(7.28)$} & $<0,001$ \\
\hline ASA score I / II & \multicolumn{2}{|c|}{$101(53.2)$} & \multicolumn{2}{|c|}{$164(54.3)$} & \\
\hline
\end{tabular}

Table 4. Clinical results observed in the two study periods.

\begin{tabular}{lccc}
\hline \multicolumn{1}{c}{ Variable } & Period pre-ACERTO & ACERTO & $p$ \\
\hline $\mathrm{SSI} *(\mathrm{n} ; \%)$ & $7 / 190(3.68)$ & $3 / 302(0.99)$ & 0.039 \\
$\begin{array}{l}\text { Length of hospital stay (median and } \\
\text { interquartile range) in days }\end{array}$ & $3(2)$ & $2(1)$ & 0.001 \\
Deaths & $2 / 190(1.05)$ & $0(0)$ & 0.14
\end{tabular}

*Surgical site infection.

\section{HOSPITALIZATION COST}

In the financial analysis, the number of nights (median) in the pre-ACERTO period was 570 for 190 patients, resulting in a cost of $R \$ 4,328.58$ per patient. In the ACERTO period, the number of nights was 604 for 302 patients and, therefore, a cost of $R \$ 2,885.72$ per patient. The cost reduction in percentage terms was approximately $66.7 \%$, equivalent to $R \$ 1,442.56$ saved per operated patient. The total sum of costs in the first phase was $R \$ 822,430.20$, and in the second phase, $R \$ 871,487.44$. In other words, with very similar financial values, approximately $59 \%$ more patients were operated on.

\section{DISCUSSION}

There was a reduction in infectious morbidity and hospital stay in hernioplasties after the implementation of the ACERTO protocol. Confirming our hypothesis, there was a reduction in hospital costs with the introduction of the new protocol. At the same time that there was a reduction in the average expenditure per operation, the turnover of beds increased, increasing the number of procedures by approximately $60 \%$ in the period after the implementation of the protocol. We highlight the importance of a public policy for modifying perioperative care, with the aim of improving results, bringing benefits to the patient, as well as to the entire 
health system. At this time, we are investigating the cost-effectiveness of this protocol for other operations in elective general surgery.

Cost is an important indicator of efficiency and is an important metric when assessing whether an intervention has led to improved quality. Even in the European ERAS protocol, some authors have investigated the cost-effectiveness, all reporting decreases in costs ${ }^{12,14}$. In most of these studies with the ERAS protocol, large operations were investigated. Nelson et al., in a study with 790 patients, identified that the implementation of the ERAS protocol in a hospital in Alberta, Canada, not only resulted in improvements in clinical results, but also had a significant beneficial impact on the scarce resources of the health system. The net cost savings attributable to the implementation of ERAS ranged from US\$1,096 to US\$2,771 per patient ${ }^{12}$. Lemanu et al. found similar results in their systematic review. From the evaluated studies, although not all were statistically significant, all demonstrated cost savings with the ERAS protocol compared with non-ERAS routines ${ }^{13}$. Joliat et al. ${ }^{14}$ also documented, in 2016, the effects of implementing the ERAS protocol in liver surgery. Seventy-four post-ERAS patients were compared with 100 pre-ERAS individuals. There was a reduction in general postoperative complications, average length of hospital stay, and costs in patients after ERAS compared with the pre-ERAS period. The cost per patient was US\$ 38,726 for the post-ERAS group compared with US $\$$ 42,356 for the pre-ERAS period. The cost minimization analysis showed a total reduction in average costs of US\$ 3,080 per patient after the implementation of ERAS.

It is important to note that in Brazil, the ACERTO protocol has been showing that this improvement with the use of modern perioperative care happens in patients undergoing medium-sized operations as well. This is relevant because in Brazilian hospitals, operations such as cholecystectomies and hernioplasties are very frequent and impact the statistics of the Unified Health System (SUS), which is observed in the DataSUS platform. In Brazil, based on the year 2019, until September, 100,345 inguinal (uni and bilateral) and incisional hernioplasty procedures were recorded, resulting in an average of 11,150 procedures per month ${ }^{15}$. If the data from this current study were reproduced in this DataSUS statistic, there could be savings of around $R \$ 144$ million only in operations of this type over 9 months of 2019. This is relevant and again points towards the modification of public perioperative care policies by SUS.

However, the data from this study must be minimized by the small number of cases studied. One should also be careful when comparing two different periods, with the possibility of different, recent improvements impacting results. However, all patients were operated on by the same group of surgeons and the time between the two periods is not very long. There were substantial changes between the two periods in the handling of perioperative care and, in our view, these may explain the results improvement.

\section{CONCLUSION}

The data set allows us to conclude that the use of the ACERTO protocol in hernioplasties not only decreases morbidity and hospital stay, but also significantly reduces hospital costs.

\section{R E S U M O}

Objetivo: comparar custos hospitalares e desfechos clínicos em hernioplastias inguinal e incisional antes e após a implementação do projeto ACERTO, em hospital universitário. Métodos: estudo retrospectivo com 492 pacientes submetidos à hernioplastias inguinais ( $n=315)$ ou incisionais $(n=177)$. A investigação envolveu duas fases: entre janeiro de 2002 e dezembro de 2005, englobando casos internados antes da implantação do protocolo ACERTO (período PRÉ-ACERTO), e outra, com casos operados entre janeiro de 2006 e dezembro de 2011, após a implantação (período ACERTO). A variável de desfecho principal foi o custo médio de internação comparando-se os dois períodos estudados. Como desfecho secundário, analisou-se tempo de internação, infecção de sítio cirúrgico e mortalidade. Foi utilizado o método de custeio do Sistema de Informação de Custos do Setor Público. Resultados: a ocorrência de infecção de sítio cirúrgico foi maior $(p=0,039)$ na primeira fase do estudo tanto para hernioplastias inguinais $(2(1,6 \%)$ versus $0(0 \%)$ casos) quanto para incisionais $(5(7,6 \%)$ versus $3(2,7 \%)$ casos). O tempo de internação diminuiu em um dia após a implementação do protocolo ACERTO $(p=0,005)$. Houve redução no custo por paciente indo de $R \$ 4.328,58$ por paciente na $1^{\text {a }}$ fase para $R \$ 2.885,72$ na $2^{a}$ fase (redução de 66,7\%). Conclusão: o conjunto de dados mostrou que houve redução da morbidade infecciosa, tempo de internação e custos hospitalares em hernioplastias após a implementação do protocolo ACERTO.

Palavras chave: Custos Hospitalares. Herniorrafia. Infecção da Ferida Cirúrgica. Cuidados Pós-Operatórios. Cuidados Pré-Operatórios. 


\section{REFERENCES}

1. Aguilar-Nascimento JE de, Bicudo-Salomão A, Caporossi C, Silva RM, Cardoso EA, Santos TP. Acerto pós-operatório: avaliação dos resultados da implantação de um protocolo multidisciplinar de cuidados peri-operatórios em cirurgia geral. Rev Col Bras Cir. 2006;33(3):181-88.

2. Fearon $\mathrm{KC}$, Ljungqvist $\mathrm{O}$, Von Meyenfeldt $\mathrm{M}$, Revhaug A, Dejong $\mathrm{CH}$, Lassen $\mathrm{K}$, et al. Enhanced recovery after surgery: A consensus review of clinical care for patients undergoing colonic resection. Clin Nutr. 2005;24(3):466-77.

3. Aguilar-Nascimento JE de, Caporossi C, BicudoSalomão A. ACERTO: acelerando a recuperação total no pós-operatório. $3^{\mathrm{a}} \mathrm{ed}$. Rio de Janeiro: Rubio; 2016.

4. Gava MG, Castro-Barcellos HM, Caporossi C, Aguilar-Nascimento JE. Enhanced muscle strength with carbohydrate supplement two hours before opencholecystectomy: a randomized, double-blind study. Rev Col Bras Cir. 2016;43(1):54-9.

5. Zani FV, Aguilar-Nascimento JE, Nascimento DB, Silva AM, Caporossi FS, Caporossi C. Benefits of maltodextrin intake 2 hours before cholecystectomy by laparotomy in respiratory function and functional capacity: a prospective randomized clinical trial. Einstein (Sao Paulo). 2015;13(2):249-54.

6. de Aguilar-Nascimento JE, Leal FS, Dantas DC, Anabuki NT, de Souza AM, Silva e Lima VP, et al. Preoperative education in cholecystectomy in the context of a multimodal protocol of perioperative care: a randomized, controlled trial. World J Surg. 2014;38(2):357-62.

7. Yu PC, Calderaro D, Gualandro DM, Marques AC, Pastana AF, Prandini JC, et al. Non-cardiac surgery in developing countries: epidemiological aspects and economical opportunities--the case of Brazil. PLoS One. 2010;5(5):e10607.

Received in: 21/12/2019

Accepted for publication: 30/03/2020

Conflict of interest: no.

Funding source: none.
8. Aguilar-Nascimento JE, Bicudo-Salomão A, Caporossi C, Silva RM, Cardoso EA, Santos TP. Enhancing surgical recovery in Central-West Brazil: the ACERTO protocol results. e-SPEN. 2008;3(2):e78-e83.

9. Bicudo-Salomão A, Meireles MB, Caporossi C, Crotti PLR, de Aguilar-Nascimento JE. Impacto do projeto acerto na morbi-mortalidade pós-operatória em um hospital universitário. Rev Col Bas Cir. 2011;38(1):310.

10. Mangram AJ, Horan TC, Pearson ML, Silver LC, Jarvis WR. Guidelines for prevention of surgical site infection. Infect Control Hosp Epidemiol. 1999;20(4):247-80.

11. Conselho Federal de Contabilidade. Resolução CFC n. 1366, de 25 de novembro de 2011. Aprova a NBC T 16.11 - Sistema de Informação de Custos do Setor Público. Disponível em: https://www.diariodasleis. com.br/legislacao/federal/218958-nbc-t-16-11sistema-de-informauuo-de-custos-do-setor-publicoaprova-a-nbc-t-16-11-sistema-de-informauuo-decustos-do-setor-publico.html. Acesso em: 2 set. 2019

12. Nelson G, Kiyang LN, Chuck A, Thanh NX, Gramlich LM. Cost impact analysis of Enhanced Recovery After Surgery program implementation in Alberta colon cancer patients. Curr Oncol. 2016;23(3):e221-7.

13. Lemanu, DP, Singh PP, Stowers MD, Hill AG. A systematic review to assess cost effectiveness of enhanced recovery after surgery programmes in colorectal surgery. Colorectal Dis. 2014;16(5):33846.

14. Joliat GR, Labgaa I, Hübner M, Blanc C, Griesser $A C$, Schäfer $M$, et al. Cost-benefit analysis of the implementation of an Enhanced Recovery Program in liver surgery. World J Surg. 2016;40(10):2441-50.

15. Ministério da Saúde(BR). Departamento de informática do SUS - DATASUS. Procedimentos hospitalares do SUS - por local de internação - Brasil. Disponível em: http://tabnet.datasus.gov.br/cgi/tabcgi.exe?sih/cnv/ qiuf.def. Acesso em: 21 nov. 2019.

\section{Mailing address:}

José Eduardo de Aguilar Nascimento

E-mail: je.nascimentocba@gmail.com 